\title{
Effect of Different Levels of Supplementary Irrigation on Yield and Yield Component of Maize (zea mays L) at Teppi, South West Ethiopia
}

\author{
Zinaw Asaye Zeleke* \\ Bonga University College of agriculture and Natural Resources
}

*Corresponding Authors: Zinaw Asaye Zeleke, Bonga University College of agriculture and Natural Resources

\begin{abstract}
Maize (zea mays L) is one of the most important cereal crops grown in Ethiopia. Field experiment was undertaken on clay loam soil at Teppi national spice research center, Ethiopia during 2013/2014 cropping season with the objectives of investigating the effect of supplementary irrigation on yield and yield component of maize for achieving maximum crop yield in rain fed agriculture during belge season. Treatments include seven levels of supplemental irrigation treatments and a control irrigation receiving no supplemental irrigation. The irrigation water was applied when the soil moisture depleted reached 55\% of total available water $(p=0.55)$. The maximum yield of 67 q/ha was recorded from 100\% ETc (Crop Evapotranspiration) which was not significantly different from $75 \%$ ETc and the minimum yield of 25q/ha was gained from rain fed treatment.
\end{abstract}

\section{INTRODUCTION}

Maize (zea mays L.) is the world's third most important cereal crop after wheat and rice grown primarily for grain and secondly for fodder (Nelson, 2005). The crop has tremendous potential as one of the main sources of food for the rapidly increasing population. The chances of increasing crop production in Sub -Saharan Africa seem to lie much in irrigated agriculture, as unreliable rainfall both interns of distribution and amount are a major limitation to agriculture in the region. Globally, irrigated maize is $17 \%$ of total acreage producing $40 \%$ of total grain yield (Carbtree et al., 1985; Popova et al., 1998).

In Ethiopia the crop is one of the leading food grains selected as to assume a national commodity crop to support the food self sufficiency program of the country. The crop is grown in a climate ranging from temperate to tropic during the period when mean daily temperatures are above $15^{\circ} \mathrm{C}$ and frost-free (Doorenbos and Kassam, 1979). In Ethiopia, maize grows under a wide range of environmental conditions between 500 to 2400 meters above sea level. Over half of Ethiopian farmers grow maize, primarily for subsistence. It is also used as feed for animals, construction materials and firewood (Kebede et al., 1993). It is thus an important crop for overall food security and for economic development in the country. The crop is one of the leading food grains selected to assume a national commodity crop to support the food self-sufficiency program of the country (Mulatu et al., 1992).

Water is one of the most important ecological factors determining crop growth and development. Maize is mainly grown under rain fed agriculture in the country. Nonetheless, it grows in wider environment and most production takes place between $21-27^{\circ} \mathrm{C}$ (Shaw, 1988) and in regions receiving rainfall of $500-700 \mathrm{~mm}$ per annum (Lafitte, 1994). In rain fed agriculture, water is the key constraint for improving agricultural productivity owing to the extreme variability of rainfall, long dry seasons, recurrent droughts, and floods and dry spells in the same season. Frequency and depth of irrigation and rain has a pronounced effect on grain yield. The effect of limited water on maize yield is considerable and careful control of frequency and depth of irrigation is required to optimize yield under conditions of water shortage. In spite of being important for world food security, the investments in rain fed agriculture, particularly in water management, have been neglected since the late 1950s.

The rainfall pattern of Teppi area is characterized by bimodal distribution with small rainy season belg (November - March) and main rainy seasons Meher (April-October) (Banti, 2009). Two varieties of subsistence agriculture are practiced in Yeki woreda in general one, in the north western corner, is based on growing cereals and enset; the other, in the rest of the woreda, is based on coffee and spices. Important cash crops in the first part include maize, teff, wheat, pulses, and enset; while in the second 
they are maize, sorghum, coffee, ginger and turmeric. Most maize crops in Teppi are produced under rain fed conditions.

Nevertheless, agricultural irrigation in the humid climate areas such as Teppi is to compensate individual cases of precipitation deficits during the vegetation period with artificial water supplies in order not only to improve but also to save crop and crop quality. Due to the importance of water to plant survival and substance, the amount applied during irrigation, time and method of application, water holding capacity of the soil and the water condition of the environment are factors that greatly influence plant growth, yield and general performance of crops.

Therefore, water is usually the most important natural factor during belge season that limit expansion and development of agriculture in sub-humid climate. The total precipitation does not meet the water requirements of maize crop in belge season. On the other hand, for the high yields, the seasonal water requirements of maize vary from 500 to $1,000 \mathrm{~mm}$ depending on the climate and the total length of the growing period. Therefore, irrigation is necessary for optimal vegetative and reproductive development in the periods of insufficient precipitation during the growing season. Therefore, to attain the highest yield of maize and achieve sustainable crop yield during belge or dry season, it is necessary to gain knowledge of the effect of different level of supplementary irrigation on maize. This research aims at identifying the appropriate supplementary irrigation level for optimum yield.

\subsection{General objective}

The general objective of this study was to investigate the effect of supplementary irrigation on yield and yield component of maize.

\subsection{Specific objectives}

- To determine maize productivity

- To determine water use efficiency

\section{RESUlTS AND DISCUSSIONS}

\subsection{Agronomic Characteristics of Maize}

\subsubsection{Days to Tasseling, Silking and Maturity}

The irrigation levels were significantly different from each other in days to tasseling, silking and days to maturity at (P0.05) significantly higher days 69.66 days to tasseling, 80.66 days to silking and 125.33 days to maturity were recorded from control treatment which is no SI, and the lower days 67.66 to tasseling, 78.33 silking and 121.66 to maturity was recorded from the treatment of $100 \%$ ETc. Tassel flowering was longer with increasing water stress. Oteiguiet al. (1995) reported that maize grain yield is particularly sensitive to water deficit that coincide with the tasseling-silking period and emergence of tassels was delayed more than two weeks. Edmeades et al. (1990) reported that, tassel flowering period was longer due to water stress conditions.

\subsubsection{Plant Height}

The results of analysis of variance showed that the different level of supplementary irrigation had highly significant $(\mathrm{P}<0.01)$ effect on plant height. The highest plant height was obtained from plot receiving $100 \% \mathrm{ETc} /$ full SI $(2.33 \mathrm{~cm})$ and had no significant difference with plots receiving $75 \% \mathrm{ETc}$. The lowest plant height was obtained from non-irrigated/ rain fed $(1.06 \mathrm{~cm})$ and significantly different to all other treatments. Richards et al and Ghodsi have reported that one of the major effects of water stress is to decrease plant height, which also caused a reduction in dry matter accumulation and subsequently plant production. Supplementary irrigation due to prolonging plant growth period increases vegetative growth which results in production of higher plants. In agreement with the result of these studies, plants height was reported to be higher with full irrigation throughout the crop growing season (Bozkurt et al., 2006).

\subsubsection{Number of Leaves per Plant}

The result of analysis variance showed that the different level of supplementary irrigation had significant differences on a number of leaves per plant (Table 8). The highest value (12) was recorded on plot of full irrigation or no stress $100 \%$ ETc, whereas, the lowest value 5.33 was observed in 
treatment of no supplementary irrigation water applied. Canopy photosynthesis is reduced by moisture stress due to reduced stomata conductance and reduction in leaf area.

As moisture stress increases, stomata start closing as a mechanism to reduce transpiration. As consequence, the entry of carbon dioxide is also reduced (Reddy et al., 2003). Leaf area expansion depends on leaf turgor, temperature and assimilates supply for growth which is all affected by drought. Leaf and stem morphology are altered by water stress. Continuous water deficit results in fewer and smaller leaves, which have smaller and more compact cells and greater specific leaf weight (Chung et al., 1997).

Leaf Area: Leaf surface area decreases as the amount of water applied to the crop also decrease. There is no significant difference in leaf area in supplementary irrigation. The maximum value $723.39 \mathrm{~cm} 2$ recorded on full irrigation and 719.83, cm2, 674.55,cm2, 670.10, $\mathrm{cm} 2,667.25, \mathrm{~cm} 2,674.55, \mathrm{~cm} 2$ and $682.55, \mathrm{~cm} 2$ were observed 75\% ETc ,50\% ETc , 25\% ETc , one SI at flowering stage ,one SI at fruit setting stage and two SI at flowering and fruit setting stage respectively.

\subsubsection{Leaf Area Index}

There was highly significant difference among irrigation level as shown in Table 8 . The maximum value 3.21 was observed from treatment of $100 \%$ ETc while the lowest 2.91 were also obtained from treatment of rain fed. Water stress reduces leaf area index (Table 8). This is due to insufficient availability of water during plant growth reduces LAI and slows down crop growth rate significantly. Water shortage during reproductive growth and before pollination, influences leaf expansion and stem development, and greatly changes the quantity of materials stored in this organ. Cicchino et al. (2010) reported that, drought stress in maize hybrids reduced pollen viability and the duration of pollination, delay flowering, reduced plant height, decreased LAI, and, finally, reduced seed and biological yields.

Table1. Effect of different irrigation levels on agronomic characteristic components of maize

\begin{tabular}{|c|c|c|c|c|c|c|c|}
\hline \multirow[t]{2}{*}{ Treatments } & \multirow[t]{2}{*}{$\operatorname{LA}\left(\mathrm{cm}^{2}\right)$} & \multirow[t]{2}{*}{ LAI } & \multirow[t]{2}{*}{ No Lev $p / p$} & \multirow{2}{*}{$\begin{array}{l}\text { Plant } \\
\text { height }(\mathrm{cm})\end{array}$} & \multicolumn{3}{|c|}{ Days } \\
\hline & & & & & Anthesis & Silking & Maturity \\
\hline Rain fed & $656.50 \mathrm{c}$ & $2.91 \mathrm{~b}$ & $5.333 \mathrm{c}$ & $1.067 \mathrm{c}$ & $80.67 \mathrm{c}$ & $69.67 b$ & $125.0 \mathrm{~b}$ \\
\hline $100 \%$ Etc & $723.39 a$ & $3.21 \mathrm{a}$ & $12 \mathrm{a}$ & $2.33 \mathrm{a}$ & $78.33 a$ & $67.67 \mathrm{a}$ & $121.7 \mathrm{a}$ \\
\hline $75 \%$ Etc & $719.83 a$ & $3.17 \mathrm{a}$ & $10 \mathrm{a}$ & $2.133 a$ & $78.67 \mathrm{a}$ & $69.00 \mathrm{a}$ & $123.3 \mathrm{a}$ \\
\hline $50 \%$ Etc & $674.55 \mathrm{~b}$ & $3.03 \mathrm{~b}$ & $7.33 b$ & $1.833 \mathrm{a}$ & $77.67 \mathrm{~b}$ & $68.33 a$ & $123.7 \mathrm{a}$ \\
\hline $25 \%$ Etc & $670.10 \mathrm{~b}$ & $2.99 \mathrm{~b}$ & $5.667 \mathrm{c}$ & $1.200 \mathrm{~b}$ & $77.67 \mathrm{~b}$ & $68.00 \mathrm{a}$ & $124.3 \mathrm{a}$ \\
\hline 1SIat flowering & $667.25 \mathrm{c}$ & $2.97 \mathrm{~b}$ & $6.33 c$ & $1.167 \mathrm{c}$ & $79.66 \mathrm{c}$ & $67.33 b$ & $124.7 \mathrm{a}$ \\
\hline $\begin{array}{l}1 \mathrm{SI} \text { at fr } \\
\text { setting }\end{array}$ & $674.55 \mathrm{~b}$ & $2.96 \mathrm{~b}$ & $6 c$ & $1.167 \mathrm{c}$ & $79.35 \mathrm{c}$ & $69.00 \mathrm{a}$ & $124.7 \mathrm{a}$ \\
\hline $\begin{array}{l}2 \text { SI at } \mathrm{fl} \text { and } \mathrm{fr} \\
\text { setting }\end{array}$ & $682.55 b$ & $2.94 \mathrm{a}$ & $9 b$ & $1.967 \mathrm{a}$ & $79.67 \mathrm{c}$ & $69.33 \mathrm{a}$ & $123.0 \mathrm{a}$ \\
\hline LSD & 4.801 & 0.02073 & 1.627 & 0.1449 & 0.984 & 0.906 & 1.331 \\
\hline $\mathrm{Cv}$ & 1.1 & 0.4 & 12.01 & 5.1 & 2.1 & 1.3 & 2.6 \\
\hline
\end{tabular}

\subsection{Effects on Maize Yield and Yield Component}

\subsubsection{Grain Yield q/ha}

The effects of various level of supplementary irrigation had a highly significant $(p<0.01)$ effect on grain yield. The maximum grain yield ( $68 \mathrm{q} / \mathrm{ha}$ ) was achieved in the treatment of full supplementary irrigation no stress $100 \%$ ETc and had significant different to all other treatments. The minimum grain yield (25 $\mathrm{q} / \mathrm{ha}$ ) was obtained from the rain fed treatment/ no SI and had significant difference to all other treatments. The reason for this is that water stress at the growing season led to water shortage at the milky stage of the seed resulting in wrinkled seeds with lower final weight. This is the main factor that reduces seed yield when there is water shortage during the final growth stages.

Guelloubi et al. (2005) and Zhang et al. (2000) reported similar results. These results also in line with report of Yazar et al. (2002), who stated that maize grain yield increased significantly by irrigation water amount and irrigation frequency. 
Karama et al. (2003) found that grain and dry matter yield, and leaf area index was affected by severity of water stress. Pandey et al. (2000) stated that yield reduction (22.6 -26.4\%) caused by deficit irrigation was associated with decreases in kernel number and weight.

Studies conducted by ICARDA and IPA Agricultural Research Center in Iraq (Adary, 2002) show that yield and water productivity can be substantially increased by using supplementary irrigation in conjunction with proper production inputs and system management.

\subsubsection{Grain weight per cob, 1000 grain weight and dry matter}

The 1000 seed weight was affected significantly $(\mathrm{p}<0.01)$ by different level of supplementary irrigation. The highest $(360.0 \mathrm{gm})$ and lowest $(243.3 \mathrm{gm})$ for 1000 seed weight were obtained from full irrigation $100 \%$ ETc irrigation application and from rainfed no SI treatments, respectively had significant difference to all other treatments in both cases. As a result 1000 grain weight increase as the amount of water increased. These results were in agreement with the results of Mansouri et al. (2010) who reported the reduction of both the 1000 grain weight and grain yield along with reduction of amount of water. Similarly, Ogreteir, (1993) reported that the application of deficit irrigation on maize at flowering period decreased the 1000 grain weight. Cakir, (2004) also stated that irrigation during milk maturation period increased 1000 grain weight.

In the present study, there is significant variation among irrigation level with respect to grain weight per cob at (0.05). The highest weight per cob 172.16 gm was recorded on irrigation level of $100 \%$ ETc and the lowest value 153.03 gm was observed from control treatment which has no SI. Eck (1985) stated that water deficiency at grain filling period reduces kernel weight per ear values.

Total dry matter: the effect of irrigation levels on accumulation of TDM showed a sharp increase in TDM by decreasing irrigation level to some extent then highly decreased as the irrigation level decreased (Table9). The maximum TDM (9.06 ton/ha) at a final harvest was accumulated by $100 \%$ ETc of irrigation level, followed by $75 \%$ ETc which gave 8.7 ton/ha. The minimum value $(8.13 \mathrm{ton} / \mathrm{ha})$ of TDM was founded from the treatment of no SI. Generally, the dry matter production under the $100 \%$ ETc irrigation was significantly higher $(\mathrm{P}<0.05)$ than those under the levels of SI treatment. Differences among treatments for TDM accumulation were due to shortage of water.

\subsubsection{Number of Row per Ear}

Irrigation level was significantly associated with number of grains per row $(\mathrm{P}<0.05)$. Significantly higher number of grin per row (40.33) was recorded on which the irrigation amount of water $100 \%$ ETc (full irrigation) applied and the lowest value (37.00) was recorded no supplementary irrigation applied. Because the quantity of grains per row is one of the most important bases of yielding component and is related to the general function directly, more the quantity of grains per row, better the function grain. In which deficit irrigation lead to a delay in insemination and distribution of granules will encountered with and finally the number of grains will decrease problem (Wasson et al., 2002).

\subsubsection{Number of cobs per Plant and Number of Grain per cob}

Irrigation level was significance difference on a number of cobs per plant at (P 0.05). The highest number of cobs per plant observed (2.33) in 100\% ETc of irrigation water applied and the lowest value (1.33) was observed from rainfed treatment. In our study, $100 \%$ ETc have no significant differences with the water amount on which $75 \%$ ETc, 50\% ETc, 25\% except the other treatment.

Irrigation amount was highly significance differences on number of grains per cob at (P 0.05). The highest grain per cob was 496.33 recorded on $100 \%$ ETc (full irrigation) and the lowest value 453.66 recorded from the treatment which is no SI or rain fed treatment. Number kernel per ear decreased with increasing deficiency in irrigation water (table 9). Similar findings were reported by Grant et al. (1989). Number of kernels per ear is yield component that varies markedly with stress. Harder et al. (1982) mentioned that water stress caused failure of kernel development, its number, size and weight.

Pandey et al. (2000) stated that kernels per ear were reduced from $20 \%$ to nearly $50 \%$ due to water stress. There is a general agreement that final kernel number is established about two to three weeks after pollination (Kirtok, 1998). Any stress imposed during this period greatly affects kernel set. Andrade et al. (1999) demonstrated that, a limited partitioning of dry matter to reproductive tissue during the critical period (bracketing, silking) results in low number of kernel set. Furthermore, ovules 
remain undeveloped, resulting in many kernels being small and light in weight. Nesmith and Ritchie, (1992) found that yield reduction in maize was attributable to a reduction in the number of welldeveloped kernels. Pandey et al. (2000) stated that yield reduction was associated primarily with decrease in kernel number and secondarily with kernel weight when deficit irrigation was imposed during vegetative and reproductive phases of growth. Bajwa et al. (1987) and Grant, (1989) have also reported significant reduction in number of grains per cob due to exposure of crop to water stress.

Table2. Effects of irrigation levels on yield and yield component of maize

\begin{tabular}{|l|c|c|c|c|c|c|}
\hline Treatment & NoRpEa & NoGpCo & NoCop P & $\begin{array}{l}1000 \text { grin } \\
\text { weight(gm) }\end{array}$ & $\begin{array}{l}\text { Grain Weight per } \\
\text { cob(gm) }\end{array}$ & $\begin{array}{l}\text { Yield } \\
(\mathrm{q} / \mathrm{ha})\end{array}$ \\
\hline Rain fed & $37.00 \mathrm{e}$ & $453.7 \mathrm{e}$ & $1.33 \mathrm{c}$ & $243.3 \mathrm{a}$ & $153.8 \mathrm{a}$ & $24.67 \mathrm{~g}$ \\
\hline 100\% Etc & $40.33 \mathrm{a}$ & $496.3 \mathrm{a}$ & $2.00 \mathrm{a}$ & $360.0 \mathrm{f}$ & $172.6 \mathrm{~g}$ & $67.66 \mathrm{a}$ \\
\hline $75 \%$ ETc & $39.66 \mathrm{~b}$ & $485.7 \mathrm{~b}$ & $2.00 \mathrm{a}$ & $333.7 \mathrm{e}$ & $169.8 \mathrm{f}$ & $61.67 \mathrm{~b}$ \\
\hline 50\%ETC & $38.33 \mathrm{~b}$ & $463.33 \mathrm{~d}$ & $1.66 \mathrm{~b}$ & $319.0 \mathrm{de}$ & $165.1 \mathrm{e}$ & $56.66 \mathrm{~b}$ \\
\hline 25\%ETC & $37.67 \mathrm{ab}$ & $454.0 \mathrm{e}$ & $1.33 \mathrm{c}$ & $301.0 \mathrm{~cd}$ & $157.40 \mathrm{c}$ & $49.55 \mathrm{~d}$ \\
\hline 1 SI at fl & $37.33 \mathrm{ab}$ & $454.33 \mathrm{e}$ & $1.33 \mathrm{c}$ & $289.3 \mathrm{bc}$ & $155.8 \mathrm{~b}$ & $49.55 \mathrm{~d}$ \\
\hline $\begin{array}{l}\text { 1 SI at fr } \\
\text { setting }\end{array}$ & $37.67 \mathrm{ab}$ & $455.0 \mathrm{e}$ & $1.66 \mathrm{~b}$ & $280.0 \mathrm{~b}$ & $159.3 \mathrm{~d}$ & $54.33 \mathrm{c}$ \\
\hline $\begin{array}{l}\text { 2 SI at fl } \\
\text { and fr }\end{array}$ & $38.67 \mathrm{~b}$ & $475.3 \mathrm{c}$ & $1.66 \mathrm{~b}$ & $274.7 \mathrm{~b}$ & $166.7 \mathrm{e}$ & $60.00 \mathrm{~b}$ \\
\hline LSD & 1.201 & 1.474 & 0.0906 & 19.75 & 1.595 & 1.455 \\
\hline CV & 1.8 & 1.2 & 31 & 3.8 & 2.6 & 1.6 \\
\hline
\end{tabular}

\section{SUMMARY AND CONCLUSION}

\subsection{Summary}

In the study, an attempt was made to evaluate the effect of different level supplementary irrigation on yield and yield component of maize in south west of SNNPR in Teppi. The aim was believed to improve water use efficiency, to investigate the effect of supplementary irrigation on yield and yield component of maize crop and to identify the level of supplementary irrigation for achieving optimum crop yield.

Irrigation level significantly affect yield and yield components considered in the study. The effect of level of irrigation on the yield component (like number of grain per row, grain yield and water use efficiency was highly significant. In parameters like number cob per plant, 1000 grain weight, number of leave of per plants significant differences but in leaf area and leave area index there was no significant difference. Similarly in most of all parameters there was no difference between 100\%ETC (full irrigation) and $75 \%$ ETc irrigation application level.

\subsection{Conclusion}

Considering the effects of water in photosynthesis, and different growth stages, there were significant impact of additional supply of water and this can be enhanced in belge season when the evapotranspiration rate is high and a signal to water use-efficiency.

It is, therefore, suggested that optimum production of Maize could be realized with rain fed supplementary irrigation. Late season cropping of Maize should be encouraged with irrigation as a means to reduce drought in case of rain failure and sustainability of Maize production.

\section{REFERENCES}

[1] Adary, A., Hachum, A., Oweis, T. and Pala, M. 2002. Wheat productivity under supplemental irrigation in northern Iraq. On-Farm Water Husbandry Research Report Series No. 2. International Center for Agricultural Research in the Dry Areas (ICARDA), Aleppo, Syria.

[2] Andrade, F.H., Vega, C., Uhart, S., Cirilo, A., Cantero, M and Valentinuz, M. 1999. Kernel number determination in maize. Crop Sci. 39: 453-459.

[3] Banti Gizaw. 2009. Geographical location and agro-ecological variation of Kaffa Zone. MSc. Thesis. Addis Ababa University, Ethiopia. Pp 33-36.

[4] Bozkurt, Y., Yazar, A., Gencel, B. and Sezen, M.S. 2006. Optimum lateral spacing for drip- irrigated corn in the Mediterranean Region of Turkey. Agricultural Water Management 85:113-120.

[5] Cakir, R. 2004. Effects of water stress at different developmental stages on vegetative and reproductive growth of Corn, field crops Research vol.89 pp1-6. 
[6] Carbtree, R.I., Yassin., A.A, Kargiugou I, and Mcnew. R.W. 1985. Effect of alternate furrow irrigation: water conservation on the yield of two Soyabean Cultivars. Agric. Water manages. , 10(3): 253- 264.

[7] Chung, S.Y., Vercellotti, J.R. and Sanders, T.H. 1997. Increase of glycolytic enzymes in peanuts during peanut maturation and curing: evidence of anaerobic metabolism. Journal of Agricultural and Food Chemestery. 45, 4516-4521

[8] Doorenbos, J and Kassam, A.K. 1979.Yield response to water. Irrigation and drainage paper no.24. FAO.Rome Italy..

[9] Edmeades, G.O., Bolano, J. and Lafitte, H.R. 1990. Selecting for drought tolerance in maize adapted to the Lowland tropics. The $4^{\text {th }}$ Asian Regional Maize Workshop, Sept. 23-27, 1990, Islambad, Pakistan .

[10] Grant, R.F., Jackson, B.S., Kiniry, J.R and Arkin, G.F. 1989. Water deficit timing effects on yield components in maize. Agronomy Journal 81: 61-65.

[11] Guelloubi, R., Hamdy, A. and Sardo. 2005. Maize production under two water saving techniques.

[12] Kebed Mengesha, Boagle Gashaw, Tolessa Birhanu, Worku Melese, Desalegne Yirga and Afeta Aman 1993. Maize production trends and research in Ethiopia, pp 4-12. In B. Tolessa, and J.K . Ransom (eds.). Proceedings of the First National Maize Workshop of Ethiopia. IAR/CIMMYT. Addis Ababa, Ethiopia.

[13] Kitrok, Y. 1998. Corn production and use. Kocaoluk press, Istanbul, Tureky pp. 445.

[14] Kumar, R. and Khepar, S.D. 1980. Decision models for optimal cropping patterns in irrigation based on crop water production functions. Agric. Water Manage., 3: 77-82.

[15] Lafitte, H.R. 1994. Identifying Production Problems in Tropical Maize. A field guide. CIMMYT (International Center for Wheat and Maize Improvement). Mexico, D.F.

[16] Nelson ,R.L. (2005). Tassel emergence and pollen shed. Corny news network.

[17] Nesmith, D.S. and Ritchie, J.T. 1992. Maize response to a sever soil water deficit during grain filling. Field Crop Research. 29: 23-35.

[18] Ogretir, K. 1993. The water-yield relationships of corn in Eskişehir conditions. PhD thesis, Irrigation and Agricultural Structures, Graduate School of Natural and Applied Sciences. Cukurova University, Adana.

[19] Otegui,M.E., Andrade, F.H. and Sureo, E.E. 1995. Growth, water use and kernel abortion of maize subjected to drought at silking. Field crops Res. 40(2): 87-94.

[20] Pandey, R.K., Maranville, J.W. and Mchetima, M.M. 2000. Deficit irrigation and nitrogen effects in Maize in Sahelian environmental II: Shoot growth, nitrogen up-take and water extraction. Agricultural water management vol. 46:15-27.

[21] Reddy, T.Y., Reddy, V.R. and Anbumozhi. 2003. Physiological responses of groundnut to drought stress and its amelioration: a critical review. Plant growth regulation. 41, 75-88.

[22] Shaw, R. H. 1988. Climate requirement. In: Sparague, G.F. and J.W. Dudley (eds).1988. Corn and Corn improvement 3rd (eds). 1988 Wisconsin, USA.

[23] Wasson, J.J., Schumacher, R.amd Wicks, T.E. 2002. Maize water content and solute potential at three stages of development. University of Illinois, Dept. of Agronomy.

[24] Yazar, A., Sezen, S.M. and Gencel, B. 2002. Drip irrigation of corn in the Southeast Anatolia Project (GAP) area in Tureky. Irrig. And Drain. 51: 293-300.

Citation: Zinaw Asaye Zeleke, “ Effect of Different Levels of Supplementary Irrigation on Yield and Yield Component of Maize (zea mays L) at Teppi, South West Ethiopia” International Journal of Research Studies in Agricultural Sciences (IJRSAS), 2020; 6(11), pp. 4-9, https://doi.org/10.20431/2454-6224.0611002

Copyright: (C) 2020 Authors. This is an open-access article distributed under the terms of the Creative Commons Attribution License, which permits unrestricted use, distribution, and reproduction in any medium, provided the original author and source are credited. 